\title{
Pelaksanaan Roya Atas Benda Bergerak di Kota Pekanbaru
}

\author{
Yelia Nathassa Winstar*, Irawan Harahap \\ Fakultas Hukum Universitas Lancang Kuning \\ Jalan Yos Sudarso Km 8, Rumbai, Kota Pekanbaru, Indonesia
}

\begin{abstract}
Abstrak
Tujuan penelitian ini untuk menjelaskan pelaksanaan roya atas benda bergerak berdasarkan Undang-Undang Nomor 42 Tahun 1999 tentang Jaminan Fidusia di Kota Pekanbaru. Metode penelitian yang digunakan penelitian hukum sosiologis. Hasil penelitian menunjukkan bahwa UUJF tidak efektif dijalankan karena adanya hambatan-hambatan. Hambatan dalam pelaksanaan roya dapat terjadi disebabkan lima faktor, yakni faktor hukumnya sendiri (undang-undang), faktor penegak hukum, pihak-pihak yang membentuk maupun menerapkan hukum, faktor sarana atau fasilitas yang mendukung penegakan hukum, faktor masyarakat, yakni lingkungan hukum tersebut berlaku atau diterapkan, faktor kebudayaan, yakni sebagai hasil karya, cipta dan rasa yang didasarkan pada karsa manusia di dalam pergaulan hidup. Dari hasil penelitian dapat disimpulkan pelaksanaan roya fidusia merupakan kewajiban hukum dalam pelaksanaannya di Kota Pekanbaru masih terdapat banyak hambatan. Hambatan ini menyebabkan tidak efektifnya pengaturan roya di Pekanbaru. Hambatan tersebut dapat dianalisis dengan menggunakan teori efektifitas.
\end{abstract}

\section{Kata Kunci: Roya, Jaminan, Fidusia}

\begin{abstract}
The purpose of this study is to explain the implementation of roya over moving objects based on Law Number 42 Year 1999 on Fiduciary Security in Pekanbaru City. The research method used is sociological law research. The results show that UUJF is not effectively implemented because of the obstacles. Obstacles in the implementation of roya can occur due to five factors, namely the legal factors themselves (law), law enforcement factors, the parties that form and apply the law, facilities or facilities that support law enforcement, community factors, namely the legal environment is applicable or applied, cultural factors, namely as a result of work, inventiveness and sense based on human initiative in the social life. From the results of the research can be concluded the implementation of fiduciary roya is a legal obligation in its implementation in Pekanbaru City there are still many obstacles. This obstacle leads to ineffective arrangement of roya in Pekanbaru. These barriers can be analyzed using the theory of effectiveness.
\end{abstract}

Keywords: Roya, Warranty, Fiduciary

"Penulis Korespondensi

E-mail: ynwinstar@unilak.ac.id 


\section{Pendahuluan}

Istilah roya tidak asing lagi dalam penjaminan di Indonesia. Roya merupakan sinonim dari penghapusan atau pencoretan jaminan. Definisi roya memang tidak ditemukan dalam Undang-Undang Nomor 42 Tahun 1999 tentang Jaminan Fidusia (selanjutnya UUJF). Definisi roya itu dapat dilihat dan sama artinya dengan Penjelasan Umum butir ke (8) UndangUndang Nomor 4 Tahun 1996 tentang Hak Tanggungan Atas Tanah Beserta Benda Benda yang Berkaitan dengan Tanah (UUHT) yang menyatakan: Pada buku tanah hak tanggungan yang bersangkutan dibubuhkan catatan mengenai hapusnya hak tersebut, sedang sertifikatnya ditiadakan. Pencatatan serupa yang disebut pencoretan atau lebih dikenal sebagai "roya" dilakukan juga pada buku tanah dan sertifikat hak atas tanah yang semula dijadikan jaminan. Sertifikat hak atas tanah yang sudah dibubuhi catatan tersebut, diserahkan kembali kepada pemegang haknya.

Dengan demikian, pengertian roya dapat diartikan sebagai penghapusan atau pencoretan suatu benda dari statusnya sebagai objek jaminan. Proses roya sendiri merupakan akibat dari adanya penjaminan benda, baik itu benda bergerak maupun tidak.

Dalam UUJF tampak bahwa penjaminan fidusia merupakan suatu rangkaian yang berkesinambungan yang seharusnya dapat dijalankan dengan tertib.Rangkaian proses dimulai dari penandatanganan perjanjian pokok berupa perjanjian utang-piutang, kredit ataupun pembiayaan. Langkah selanjutnya penandatanganan perjanjian jaminan fidusia sebagai perjanjian accessoir yang wajib dibuat oleh
notaris.Setelah penandatanganan Akta Jaminan Fidusia kemudian didaftarkan pada sistem fidusia online. Tahap terakhir dari rangkaian proses ini disebut roya/penghapusan, artinya perjanjian berakhir bila perjanjian pokok berakhir.

Terkait dengan roya dalam Pasal 25 Ayat (3) UUJF dinyatakan bahwa penerima fidusia wajib memberitahukan kepada Kantor Pendaftaran Fidusia mengenai hapusnya jaminan fidusia dengan melampirkan pernyataan mengenai hapusnya utang, pelepasan hak, atau musnahnya benda yang menjadi obyek jaminan fidusia tersebut. Namun, pada kenyataannya pelaksanaan roya ini seringkali diabaikan oleh penerima fidusia. Dari studi singkat yang pernah dilakukan Kelompok Bank Dunia-IFC terhadap tingkat kepatuhan pencabutan fidusia pada pendaftaran jaminan fidusia konvensional sebelum fidusia online berlaku hanya berkisar di bawah $10 \%{ }^{1}$ Setelah berlakunya fidusia online pun dari penelitian pendahuluan yang dilaksanakan peneliti di perusahaan pembiayaan dan notaris, tidak melihat adanya peningkatan yang drastis dalam pendaftaran roya. Masih banyak penerima fidusia yang lalai dalam melakukan pencoretan jaminan fidusianya. Kenyataan ini umumnya terjadi pada benda bergerak. Hal ini tentu merugikan pemberi fidusia selaku pemilik objek jaminan.

Tidak efektifnya suatu aturan menurut Menurut Soerjono Soekanto dalam teori efektifitas hukum bahwa efektif atau tidaknya suatu hukum ditentukan oleh 5 (lima) faktor, yaitu Pertama, faktor hukumnya sendiri (undang-undang). Kedua, faktor penegak hukum, yakni pihak-pihak yang membentuk

${ }^{1}$ Aria Suyudi, Pembaruan Pendaftaran Jaminan Fidusia dan Implikasinya Bagi Akses Terhadap Pembiayaan Indonesia, http://www. hukumonline. com/berita/baca/ It555a9a3744b97/ pembaruan-pendaftaran -jaminan-fidusia-dan-implikasinya-bagi-akses- terhadap-pembiayaan-indonesia-broleh-aria-suyudi-sh- $\| \mathrm{m}$ , diakses pada tanggal 25 Desember 2015. 
maupun menerapkan hukum. Ketiga, faktor sarana atau fasilitas yang mendukung penegakan hukum. Keempat, faktor masyarakat, yakni lingkungan hukum tersebut berlaku atau diterapkan. Kelima, faktor kebudayaan, yakni sebagai hasil karya, cipta dan rasa yang didasarkan pada karsa manusia di dalam pergaulan hidup. ${ }^{2}$

Dari penelitian yang dilakukan oleh Jatmiko Winarno menggambarkan bahwa pendaftaran fidusia sangat penting dilakukan. Dalam penelitian tersebut ia menyatakan bahwa pendaftaran diharapkan memberikan kepastian hukum kepada pemberi dan penerima fidusia maupun kepada pihak ketiga. Selanjutnya, ia menjelaskan bahwa apabila perjanjian pokoknya berupa utang piutang telah hapus maka perjanjian fidusia sebagai perjanjian accesoir juga turut hapus. Namun, berkaitan dengan ketentuan Pasal 25 Ayat (3) UUJF agar memberikan kepastian hukum kepada Kantor Pendaftaran Fidusia diperintahkan untuk melakukan pencoretan terhadap pencatatan jaminan fidusia dari Buku Daftar Fidusia atas permintaan penerima fidusia serta menerbitkan surat keterangan yang menyatakan bahwa Sertifikat jaminan Fidusia yang bersangkutan tidak berlaku lagi. ${ }^{3}$ Namun, dalam penelitian ini ia hanya membahas mengenai perlindungan hukum bagi kreditur yang menitikberatkan pada kewajiban. Sementara itu, penelitian yang dilakukan Miranda Fitraya menyimpulkan bahwa pada prinsipnya roya hak tanggungan wajib dilakukan. Namun, dalam praktiknya tidak ada aturan yang tegas menyatakan bahwa pihak yang tidak segera melakukan roya akan diberikan sanksi sehingga implementasi dari Undang-Undang Nomor 4 Tahun 1999 (UUHT) terkait pasal roya belum efektif dilaksana kan. ${ }^{4}$

Penelitian mengenai fidusia sangat banyak, hanya saja sebagian besar membahas tentang pentingnya pendaftaran jaminan fidusia guna perlindungan bagi para pihak. Akan tetapi, penelitiantentang pelaksanaan roya fidusia pada benda bergerak di Kota Pekanbaru belum pernah dilakukan. Kalaupun ada, penelitian dibidang roya hanya mengenai roya hak tanggungan. Oleh karena itu, penelitian yang penulis lakukan merupakan suatu kebaharuan (novelty) sekaligus memberikan konstribusi dalam pengetahuan. Adapun permasalahan dalam penelitian ini berangkat dari pertanyaan: Pertama, bagaimana pelaksanaan roya fidusiapada benda bergerak di Kota Pekanbaru berdasarkan Undang-Undang Nomor 42 Tahun 1999 tentang Jaminan Fidusia? Kedua,faktorfaktor apakah yang menjadi penghambat dalam pelaksanaan roya fidusia pada benda bergerak di Kota Pekanbaru. Ketiga,upaya apakah yang dilakukan oleh Pemerintah dalam mengatasi hambatan pelaksanaan roya fidusia pada benda bergerak di Kota Pekanbaru?

Untuk menjawab pertanyaan tersebut penulis mengunakan pendekatan hukum sosiologis. Tujuan penelitian ini untuk menjelaskan pelaksanaan roya atas benda bergerak berdasarkan Undang-Undang Nomor 42 Tahun 1999 tentang Jaminan Fidusiadi Kota Pekanbaru.

\footnotetext{
${ }^{2}$ Soerjono Soekanto, Faktor-faktor yang Mempengaruhi PenegakanHukum, (Jakarta: PT Raja Grafindo Persada, 2008), hlm. 8.

${ }^{3}$ Jatmiko Winarno.Perlindungan Hukum Bagi Kreditur Pada Perjanjian Jaminan Fidusia,Jurnal Independent, Volume 1, Nomor 1, Maret 2013, hlm. 52.

${ }^{4}$ Miranda Fitraya,Akibat Hukum Terhadap Jaminan Fidusia yang Didaftarkan saat Terjadinya Kemacetan Pembayaran, Jurnal Braja Niti, Volume 1, Nomor 9, Tahun 2012, hlm. 12.
} 


\section{Metode Penelitian}

Artikel ini merupakan hasil penelitian, yang merupakan jenis penelitian hukum sosiologis atau jenis penelitian lapangan (field research) yang mana data yang dipakai bersumber dari penelitian di lapangan serta didukung dengan data kajian kepustakaan. Data dari penelitian di lapangan menjadi data primer, sedangkan data dari kajian kepustakaan merupakan bahan hukum primer yang bersifat autoritatif, artinya mempunyai otoritas. Metode pendekatannya yuridis sosiologis, yaitu pendekatan dilakukan dengan melihat hukum yang berlaku dalam masyarakat. Analisisdata menggunakan metode kualitatif, yakni mendeskripsikan data yang diperoleh dalam kalimat-kalimat secara naratif. Dalam mengambil kesimpulan digunakan metode induktif, yakni menarik kesimpulan dari pernyataan yang bersifat khusus ke dalam pernyataan yang bersifat umum.

\section{Pembahasan}

\section{Pelaksanaan Jaminan Fidusia dalam Hukum} Jaminan di Indonesia

Lembaga Jaminan di Indonesia telah dikenal dari ratusan tahun yang lalu. Ketika rezim hukum adat, masyarakat adatmengenal adanya gadai. Hampir seluruh jaminan dinamai dengan gadai. Demikian itu, dapat dimaklumi karena hukum adat tidak membedakan antara benda bergerak dan tidak bergerak. Pada saat ini Indonesia telah berbentuk Negara Kesatuan Republik Indonesia (NKRI), Kitab UndangUndang Hukum Perdata (KUH Perdata) sebagai aturan dasar dalam keperdataan mengenal berbagai macam penjaminan. Jaminan dibagi menjadi dua bagian, yakni jaminan perorangan dan jaminan kebendaan. Sementara itu, jaminan kebendaan dapat dibagi berdasarkan jenis bendanya, yaitu benda bergerak atau benda tidak bergerak.

Salah satu jenis jaminan benda bergerak yang sangat banyak dipergunakan, tetapi jarang dipahami masyarakat awam ialahjaminan fidusia. Jaminan fidusia adalah hak jaminan atas benda bergerak baik yang berwujud maupun yang tidak berwujud dan benda tidak bergerak khususnya bangunan yang tidak dapat dibebani hak tanggungan. Meskipun lembaga jaminan fidusia telah ada sejak dari jaman Kolonial Belanda, namun dalam kurun waktu lima tahun belakangan eksistensi lembaga jaminan fidusia sangat populer seiring dengan pertumbuhan lembaga pembiayaan. Berdasarkan laporan hasil survei yang dilakukan oleh Otoritas Jasa Keuangan (OJK) dituangkan dalam Buku Data Statistik Lembaga Pembiayaan Tahun 2014 yang diposting pada website OJK memperlihatkan bahwa pertumbuhan lembaga pembiayaan meningkat dalam kurun waktu 2010-2014 dari 192 di tahun 2010 menjadi 201 ditahun $2014 .^{5}$

Secara yuridis formal pertama kali lembaga jaminan fidusia di Indonesia mendapatkan pengakuan dalam Putusan Mahkamah Agung tanggal 18 Agustus 1932 dalam kasus Battafsche Petroleum Maatschappij (BPM) cs Pedro Clignett. ${ }^{6}$ Kemudian guna adanya kepastian hukum maka diaturlah dalam suatu peraturan perundang undangan, yakni Undang Undang Nomor 42 Tahun 1999 tentang Jaminan Fidusia

${ }^{5}$ Buku Data Statistik Lembaga PembiayaanTahun 2014, http: //www.ojk. go.id/id/ kanal/iknb/data-danstatistik/lembaga-pembiayaan/Pages/Statistik-Lembaga-Pembiayaan -2015.aspx, diakses pada tanggal 13 September 2016.

${ }^{6}$ Tan Kamello, Hukum Jaminan Fidusia, Suatu Kebutuhan yang Didambakan, (Bandung: Alumni, 2014), hIm. 3 . 
(selanjutnya disebut sebagai UUJF). Terhitung dari masa pembentukannya hingga saat ini sudah sangat banyak perkembangan terjadi dalam penjaminan fidusia. Perbaikan-perbaikan pengaturan dalam lingkup fidusia sangat berkembang selayaknya hukum yang responsif.

Dalam UUJF tampak bahwa penjaminan fidusia merupakan proses yang berkesinambungan. Sebelum masuk pada proses pembebanan fidusia, tahapan yang dilakukan membuat perjanjian pokok terlebih dahulu baik berbentuk perjanjian kredit ataupun perjanjian pembiayaan yang prinsipnya adanya utang piutang antara kreditur dan debitur. Setelah perjanjian pokok ditandatangani kemudian masuk pada pembebanan jaminan fidusia dengan dibuat Akta Jaminan Fidusia sebagai perjanjian accesoir (perjanjian pengikutan) dari perjanjian pokok tersebut. Selanjutnya, jaminan tersebut didaftarkan pada situs fidusia online guna memenuhi asas publisitas dan tahapan terakhir dalam proses penjaminan fidusia berupa penghapusan (roya) guna melepaskan status jaminan yang membebani objek jaminan fidusia. Rangkaian proses tersebut dapat dilihat dalam gambar berikut:

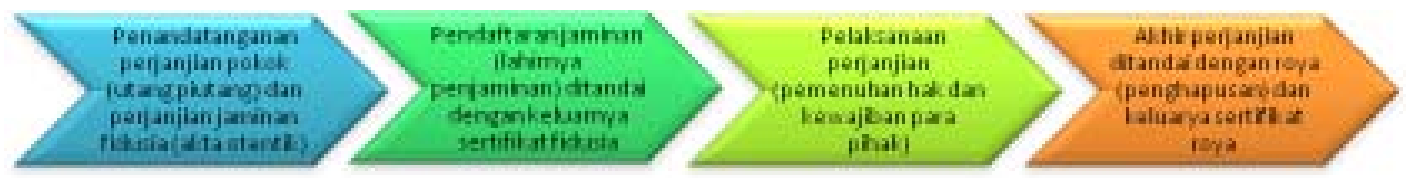

Gambar 1. Rangkaian Proses Penjaminan Fidusia

Pendaftaran jaminan fidusia merupakan salah satu bentuk fasilitas penunjang kepastian hukum dalam hukum jaminan fidusia. ${ }^{7}$ Demikian pula, penghapusan (roya) jaminan fidusia guna memberikan kepastian hukum kepada masyarakat khususnya kepada pemberi fidusia.

Pendaftaran fidusia memiliki arti penting karena UUJF secara eksplisit menyatakan bahwa jaminan fidusia lahir pada tanggal yang sama dengan tanggal dicatatnya jaminan fidusia dalam Buku Daftar Fidusia ketentuan ini terdapat dalam Pasal 14 Ayat (3) UUJF. Artinya, pendaftaran merupakan momentum lahirnya hak preferen dari kreditur penerima jaminan fidusia. Bukan hak preferen saja yang diterima oleh kreditur dari adanya pendaftaran tersebut, tetapi juga dapat memberikan hak eksekutorial yang dibawa oleh sertifikat fidusia yang memiliki irah-irah "DEMI KEADILAN BERDASARKAN KETUHANAN YANG MAHAESA".
Irah-irah ini membawa konsekuensi hukum bahwa sertifikat jaminan fidusia tersebut dipersamakan dengan putusan pengadilan yang telah memiliki hukum tetap. Oleh karenanya, apabila debitur cidera janji maka penerima fidusia memiliki hak untuk menjual benda yang menjadi objek jaminan atas kekuasaannya sendiri baik melalui pelelangan umum atau dibawah tangan bila disepakati oleh kedua belah pihak dan memperoleh harga tertinggi. Hal ini tercantum dalam Pasal 29 Ayat(3) UUJF.

Meskipun UUJF telah ada semenjak tahun 1999 ,tetapi gaung pendaftaran fidusia marak disaat keluarnya Peraturan Menteri Keuangan Nomor 130/PMK.010/2012 tentang Pendaftaran Jaminan Fidusia Bagi Perusahaan Pembiayaan yang Melakukan Pembiayaan Konsumen Untuk Kendaraan Bermotor dengan Pembebanan Jaminan Fidusia (selanjutnya disebut Permenkeu 130).

${ }^{7}$ lbid. 
Semenjak adanya Permenkeu ini pendaftaran fidusia mengalami peningkatan. Sebagaimana dikutip dari madiunpos.com atas wawancara terhadap Kepala Seksi Evaluasi dan Laporan Direktorat Jenderal Administrasi Hukum Umum (AHU) Kementerian Hukum dan HAM Yudi Yuliadi, ia menyatakan "bahwa periode 5 Februari-6 Maret 2017 ada 638.634 pemohon yang mengajukan fidusia melalui sistem online". Menurutnya,"angka tersebut terus mengalami peningkatan seiring berbagai kemudahan yang bisa diterima masyarakat". Selanjutnya ia menyatakan "terjadi peningkatan manual ke sistem online sebesar 666 persen sejak 2013 yang tadinya tidak mendaftar jadi daftar". 8

Sanksi administratif yang tertera dalam Pasal 5 Permenkeu 130 akan diterima oleh lembaga pembiayaan bila tidak mendaftarkan fidusianya. Sanksi tersebut agaknya dapat memaksa lembaga pembiayaan untuk mematuhi keharusan pendaftaran tersebut khususnya pada kendaraan bermotor yang memang merupakan objek jaminan yang paling banyak didaftarkan seiring berkembangnya lembaga pembiayaan.

Peningkatan volume pendaftaran fidusia mengharuskan Kemenkumham untuk mencari cara percepatan proses pendaftaran yang terkendala karena adanya penumpukan berkas yang dikerjakan secara manual di KPF (Kantor Pendaftaran Fidusia. Akibatnya proses pendaftaran fidusia hingga terbitnya sertifikat memakan waktu yang sangat lama. Oleh karenanya, Kemenkumham mengeluarkan Surat Edaran Direktur Jenderal Administrasi Hukum Umum (AHU) No.AHU/06.OT-03.01 Tahun 2013 tentang Pemberlakuan Sistem Administrasi Pendaftaran Jaminan Fidusia Secara Elektronik (Online System) yang berlaku mulai 5 Maret 2013 diseluruh KPF. KPF tidak lagi menerima permohonan pendaftaran jaminan fidusia secara manual. Peraturan tersebut berlaku untuk semua permohonan pendaftaran fidusia baik kendaraan bermotor maupun benda bergerak dan tidak bergerak lainnya yang merupakan objek jaminan fidusia. Munculnya fidusia online pada generasi awal hanya memberikan fasilitas pendaftaran. Namun, pada saat ini seluruh rangkaian proses tersebut dapat dilakukan melalui fidusia online.

\section{Pelaksanaan Roya Jaminan Fidusia Pada Benda Bergerak di Kota Pekanbaru}

Kewajiban roya berdasarkan UUJF dinyatakan dalam Pasal 25 Ayat (3): "Penerima fidusia memberitahukan kepada Kantor Pendaftaran Fidusia mengenai hapusnya jaminan fidusia sebagaimana dimaksud dalam Ayat (1) dengan melampirkan pernyataan mengenai hapusnya utang, pelepasan hak, atau musnahnya benda yang menjadi obyek jaminan fidusia tersebut".

Roya merupakan penutup dari suatu rangkaian proses jaminan kebendaan baik itu jaminan benda bergerak maupun tidak bergerak. Rangkaian proses penjaminan sebagaimana tampak pada gambar di atas merupakan rangkaian yang sesungguhnya tidak dapat dipenggal salah satunya karena akan menghilangkan hakekat dari pelaksanaan penjaminan itu sendiri, yakni memberikan kepastian hukum.

Sistem fidusia online tidak hanya menyajikan pendaftaran fidusia saja, tetapi juga untuk penghapusan (roya) fidusia sebagai bagian akhir dari proses suatu penjaminan, seperti gambar di bawah ini:

${ }^{8} \mathrm{http}: / / m$. madiunpos. Com/2017/03/06/pengajuan-permohonan-fidusia-jumlah-pemohon-lewat-onlinemeningkat-799183, diakses pada tanggal 20 Agustus 2017. 


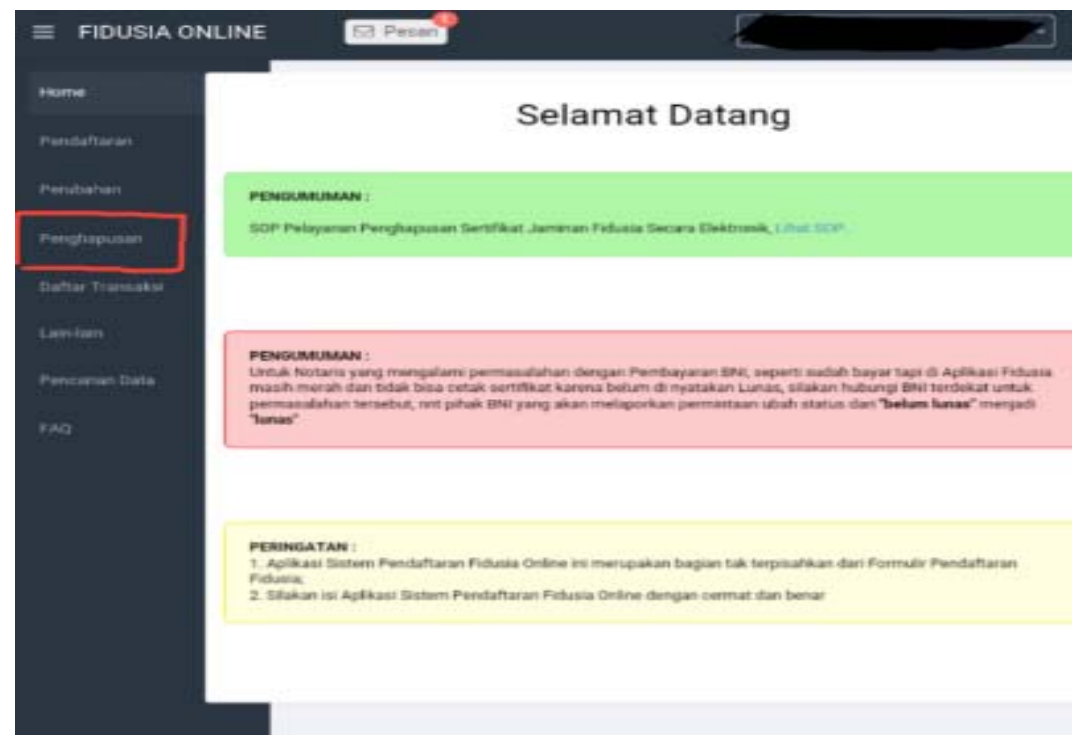

Gambar 2. Aplikasi Fidusia Online ${ }^{9}$

Pelaksanaan roya fidusia ini merupakan kewajiban yang tercantum dalam Pasal 25 Ayat (3) UUJF yang kemudian kewajiban ini ditegaskan kembali dalam Peraturan Pemerintah Nomor 21 Tahun 2015 tentang Tata Cara Pendaftaran Jaminan Fidusia dan Biaya Pembuatan Akta Jaminan Fidusia sebagai peraturan pelaksana yang menggantikan Peraturan Pemerintah Nomor 86 Tahun 2000 dengan judul yang sama. Pasal 16 Ayat (2) menyatakan bahwa "dalam hal jaminan fidusia hapus sebagaimana dimaksud pada Ayat (1) maka penerima fidusia, kuasa atau wakilnya, wajib memberitahukan kepada menteri dalam jangka waktu paling lama 14 (empat belas) hari terhitung sejak tanggal hapusnya jaminan fidusia".

Selanjutnya, penyebab hapusnya jaminan fidusia dapat ditemui dalam Pasal 25 Ayat(1) UUJF, karena:

a. hapusnya utang yang dijamin dengan fidusia. b. pelepasan hak atas jaminan fidusia oleh penerima fidusia.

c. musnahnya benda yang menjadi obyek jaminan fidusia.

Namun, dalam fidusia online jenis penghapusan hanya ada dua, yakni penghapusan karena pelunasan dan penghapusan karena pelepasan hak. Berbeda,dengan pendaftaran fidusia yang mengalami peningkatan yang luar biasa semenjak keluarnya Permenkeu, penghapusan fidusia tidak mengalami lonjakan signifikan. Dari studi singkat yang pernah dilakukan Kelompok Bank Dunia-IFC terhadap tingkat kepatuhan pencabutan fidusia pada pendaftaran jaminan fidusia konvensional sebelum fidusia online berlaku hanya berkisar di bawah $10 \% .^{10}$

Meskipun pendaftaran maupun penghapusan saat ini dapat dilakukan oleh korporasi, retail dan Kanwil Kemenkumham langsung selain oleh notaris. Namun, kenyataannya di wilayah Pekanbaru khususnya belum dapat

${ }^{9}$ Lihat https://fidusia.ahu.go.id/home.html.

${ }^{10}$ Aria Suyudi, Pembaruan Pendaftaran....Loc. Cit. 
meningkatkan kepatuhan terhadap pelaksanaan roya sebagaimana semestinya.

Berdasarkan wawancara penulis dengan Notaris H.Masrijal, S.H.,M.Kn seorang notaris wilayah kerja di Kota Pekanbaru, ia menerangkan bahwa "dalam Fidusia Online terdapat dua sebab roya (penghapusan): pertama, penghapusan karena pelunasan, kedua, penghapusan karena pelepasan hak". Selanjutnya, ia menerangkan bahwa "perusahaan pembiayaan yang biasa mendaftarkan fidusia dengannya cukup banyak". Hanya saja, "untuk roya ia mengatakan jarang sekali perusahaan pembiayaan yang memiliki hubungan kerjasama dengannya melakukan pendaftaran roya". "la pun tidak dapat melakukan inisiatif melakukan roya karena permohonan penghapusan itu harus datang dari kreditur sebagai penerima fidusia". ${ }^{11}$

Untuk mengetahui hal ini, penulis melakukan wawancara dengan seorang Head Administration pada sebuah perusahaan pembiayaan PT Summit Oto Finance cabang Pekanbaru yang bergerak pada pembiayaan kendaraan bermotor jenis roda dua. Ia mengatakan bahwa "roya dilakukan bila terjadi pelepasan haksaja". Akan tetapi, "bagi pelunasan kredit tidak dilakukan roya karena bukan kewajiban kreditur". ${ }^{12}$

Pernyataan ini sesungguhnya bertentangan dengan Pasal 25 Ayat (3) dinyatakan bahwa "penerima fidusia memberitahukan kepada kantor pendaftaran fidusia mengenai hapusnya jaminan fidusia sebagaimana dimaksud dalam Ayat (1) dengan melampirkan pernyataan mengenai hapusnya utang, pelepasan hak, atau musnahnya benda yang menjadi objek jaminan fidusia tersebut". Dengan demikian, maka seharusnya kreditur sebagai penerima fidusia berkewajiban untuk melakukan roya.

Dalam wawancara penulis dengan Administration Head PT Oto Mulitartha Cabang Pekanbaru menyatakan bahwa "perusahaannya telah aktif melakukan pendaftaran fidusia, bahkan sebelum adanya Permenkeu". Setelah adanya Permenkeu perusahaannya mewajibkan seluruh penjaminan harus dibuatkan akta jaminan fidusia dan didaftarkan. Selanjutnya, ia menerangkan bahwa "roya dilakukan perusahaan bila terjadi pelepasan hak". Dari lebih kurang 300 jaminan yang didaftarkan perbulan, hanya maksimal 50 jaminan saja yang kemudian di roya karena terjadinya pelepasan hak. Lebih jauh ia menerangkan bahwa "untuk pendaftaran roya karena pelunasan tidak pernah dilakukan, karena ia tidak tahu bahwa itu merupakan kewajiban dari kreditur". ${ }^{13}$

Hal senada juga dinyatakan oleh pegawai Pegadaian Syari'ah Cabang Ahmad Yani bernama Risye yang menyatakan bahwa "ia tidak melaksanakan roya karena ia tidak mengetahui bahwa roya merupakan suatu kewajiban dari penerima fidusia bila penjaminan itu berakhir" ${ }^{14}$

Pendaftaran yang merupakan momentum terjadinya penjaminan maka roya fidusia sesungguhnya merupakan momentum berakhirnya suatu jaminan fidusia. Baik pendaftaran maupun roya merupakan kewajiban kreditur sebagai penerima fidusia. Hanya saja pelaksanaannya mengalami banyak kendala

\footnotetext{
${ }^{11}$ Wawancara dengan H. Masrijal, S.H., M.Kn Notaris di Kota Pekanbaru pada tanggal 12 Juni 2017.

${ }^{12}$ Wawancara dengan salah seorang Administration Head pada tanggal 21 Agustus 2017.

${ }^{13}$ Ibid.

${ }^{14}$ Wawancara dengan Risye pegawai PT Pegadaian Syari'ah Cabang Ahmad Yani pada tanggal 8 Mei
} 2017 
meskipun sesungguhnya menurut Notaris Merry Berlian Pahalmas, S.H.,M.Kn "fidusia online memberikan kemudahan dalam pendaftaran dan penghapusan jaminan fidusia". Hanya saja pendaftaran roya jaminan belum banyak dipatuhi oleh kreditur. Selanjutnya, ia mengatakan bahwa "permohonan roya seharusnya datang dari kreditur dan biasanya ia melakukan roya bila terjadi pelepasan hak". la juga menambahkan bahwa "regulasi ini masih banyak kelemahan". "Tidak efektifnya roya menyangkut pada instansi yang mengeluarkan bukti kepemilikan kendaraan dengan instansi yang mengeluarkan sertifikat fidusia sehingga tidak ada harmonisasi menyangkut pendaftaran dan penghapusan atau roya". ${ }^{15}$ Sama halnya dengan Notaris Ashelfine, S.H. melalui pegawainya yang diberi tugas untuk mendaftarkan roya mengatakan bahwa "ia mengakui pernah mendaftarkan roya, tetapi karena akibat pelepasan hak tidak pernah melakukan roya". la menambahkan alasannya tidak melakukan roya "karena tidak ada permintaan dari perusahaan pembiayaan untuk meroya setiap pelunasan utang". ${ }^{16}$

Berdasarkan wawancara dari 5 pemberi fidusia ditempat terpisah yang masing-masing bernama Wiendha, Zamrinaldi, Romi, Prescilla dan Jimmy seluruhnya pernah menjadi konsumen dari lembaga pembiayaan bahwa mereka tidak tahu apa arti roya dan tidak tahu bahwa objek jaminan mereka harus di roya bila terjadi pelepasan hak atau pelunasan.

M.Bahsan menyatakan bahwa terhadap objek jaminan kredit yang diikat dengan suatu lembaga jaminan, seperti hipotek, hak tanggungan atau jaminan fidusia, harus dilakukan pembebasan pembebanannya. Sepanjang pembebanan objek jaminan kredit dilakukan melalui kewajiban pendaftaran, penghapusan dan pembebanan utang terhadap objek jaminan kredit tersebut dilakukan oleh instansi tempat dilakukannya pendaftaran pembebanan. ${ }^{17}$

Meskipun aturan roya telah diatur dalam UUJF dan Peraturan Pemerintah Nomor 21 Tahun 2015 dan telah disertai pula dengan fidusia online yang dapat memudahkan masyarakat namun berdasarkan hasil wawancara, pelaksanaan fidusia tidak efektif dilaksanakan oleh kreditur.

\section{Akibat Hukum Tidak Dilakukannya Roya (Penghapusan) Atas Objek Jaminan Fidusia yang Didaftarkan}

Aturan roya yang diatur dalam Pasal 25 UUJF dan ditegaskan kembali dalam Peraturan Pemerintah Nomor 21 Tahun 2015 membebankan kewajiban itu kepada kreditur selaku penerima fidusia. Tidak dilaksanakannya roya tentu saja akan menimbulkan permasalahan hukum.

Tiap-tiap jaminan membawa sifat droit de suietyang merupakan salah satu ciri hak kebendaan. Droit de suiet sendiri bermakna suatu hak yang terus mengikuti pemilik benda atau hak yang mengikuti bendanya ditangan siapapun (het recht volgt de eigendom van de zaak). Hak kebendaan adalah hak absolut, yang berarti hak yang melekat pada suatu benda, memberikan kekuasaan langsung atas benda tersebut dan dapat dipertahankan terhadap

${ }^{15}$ Wawancara Notaris Merry Berlian Pahalmas, S.H., M.Kn pada tanggal 12 Juni 2017.

${ }^{16}$ Wawancara dengan pegawai Ashelfine, S.H. pada tanggal 12 Juni 2017.

${ }^{17}$ M.Bahsan, Hukum Jaminan dan Jaminan Kredit Perbankan Indonesia, (Jakarta: Raja Grafindo Persada, 2008), hlm.147. 
tuntutan oleh setiap orang. ${ }^{18}$ Oleh karenanya, apabila suatu benda telah memiliki status sebagai objek jaminan fidusia maka akan selalu melekat pada bendanya ditangan siapapun ia berada sampai penjaminannya itu hapus.

Lazimnya perjanjian jaminan kebendaan dikonstruksikan sebagai perjanjian yang bersifat accesoir (tambahan) yang keberadaannya digantungkan pada perjanjian pokok, yaitu perjanjian kredit. Perjanjian accessoir selalu mengikuti perjanjian pokoknya sehingga jika perjanjian pokoknya berakhir atau hapus maka secara otomatis perjanjian accesoir akan berakhir atau hapus pula. Dengan demikian, keberadaan perjanjian accesoir, tergantung dari ada atau tidak adanya perjanjian pokok. ${ }^{19}$ Perjanjian fidusia merupakan perjanjian accessoir, oleh karenanya berlaku pulalah baginya sifat accessoir tersebut. Namun, berakhirnya suatu jaminan fidusia oleh undangundang tidak dapat begitu saja terjadi. UUJF memerintahkan adanya penghapusan guna mengakhiri status jaminan tersebut.

Penjelasan Pasal 25 juga menyatakan, "sesuai dengan sifat ikutan dari jaminan fidusia maka adanya jaminan fidusia tergantung pada adanya piutang yang dijamin pelunasannya". Apabila piutang tersebut hapus karena hapusnya utang atau karena pelepasan maka dengan sendirinya jaminan fidusia yang bersangkutan menjadi hapus". Meskipun demikian, kewajiban melaksanakan roya diatur lebih lanjut dalam Pasal 25 Ayat(3) yang dipertegas oleh Pasal 16 Peraturan Pemerintah Nomor 21 Tahun 2015 tentang Tata Cara
Pendaftaran Jaminan Fidusia dan Biaya Pembuatan Akta Jaminan Fidusia sebagai peraturan pelaksananya. Apabila roya tidak dilaksanakan oleh kreditur maka tentu saja akan menyebabkan adanya permasalahan hukum dikemudian hari.

Permasalahan hukum pertama, seperti yang dijelaskan oleh $\mathrm{M}$. Bahsan, la mengatakan "terhadap objekjaminan fidusia yang belum diroya,tidak bisa dijadikan sebagai jaminan”.Jika objek jaminan tersebut ingin dijaminkan kembali sebagai objek jaminan fidusia maka objek tersebut harus diroya terlebih dahulu. Terkait dengan objek jaminan fidusia yang difidusiakan kembali, padahal belum dilakukan roya fidusia termasuk kedalam fidusia ulang dan hal itu dilarang oleh undang-undang jaminan fidusia. ${ }^{20}$

Terkait Pasal 35, 36 dan 28 UUJF pemberi fidusia akan sangat dirugikan bila roya tidak dilakukan oleh penerima fidusia yang berkehendak menjaminkan kembali benda bergerak miliknya tersebut. Pasal 36 UUJF melarang adanya fidusia ulang bahkan memberikan ancaman pidana bila fidusia ulang dilakukan oleh pemberi fidusia. Namun, dalam hal pemberi fidusia tidak mengetahui bahwa benda bergeraknya belum dilepaskan atau diroya dari status jaminan oleh penerima fidusia maka pemilik jaminan tetap akan dapat dipidana karena melakukan fidusia ulang.

Unsur-unsur pidana yang harus dipenuhi supaya pelaku dapat dituntut berdasarkan Pasal 36 UUJF, yaitu Pertama,pemberian fidusia yang mengalihkan, menggadaikan atau menyewa-

\footnotetext{
${ }^{18}$ Frieda Husni Hasbullah, Hukum Kebendaan Perdata, Hak-Hak yang Memberi Kenikmatan Jilid I, (Jakarta: Ind-Hill-Co, 2005), hlm. 52.

${ }^{19}$ Mokhamad Khoirul Huda dan Ninis Nugraheni, Perjanjian Jaminan Sebagai Accessoir Perjanjian Kredit, Jurnal Dialogia Iuridica, Volume 6, Nomor 2, Tahun 2015, hlm.19.

${ }^{20}$ Opia Rendra, Tinjauan Yuridis Terhadap Fidusia Ulang Objek Tanpa Roya Fidusia Berdasarkan UndangUndang Nomor 42 Tahun 1999,JOM Fakultas Hukum, Volume II, Nomor 2, Oktober 2015, hlm.10.
} 
kan. Kedua, benda obyek fidusia. Ketiga, tanpa persetujuan tertulis. Keempat, penerima fidusia dari hasil pembahasan tersebut maka jika semua persyaratan tidak dijalani atau ditepati maka akan dikenakan sanksi pidana dan denda berdasarkan undang-undang yang berlaku di wilayah Indonesia. ${ }^{21}$

Kerugian lain yang akan dialami oleh pemberi fidusia bila dilihat dalam ketentuan Pasal 28 UUJF yang menyatakan apabila atas benda yang sama menjadi obyek jaminan fidusia lebih dari 1 (satu) perjanjian jaminan fidusia maka pihak kreditur yang lebih dahulu mendaftarkannya merupakan penerima fidusia. Hal ini akan merugikan kreditur baru yang tidak mengetahui objek jaminan belum dilakukan roya. Meskipun Sisminbakum menjunjung asas publisitas, yaitu masyarakat dapat melakukan pengecekan status suatu benda sedang dijaminkan atau tidak. Namun, kendala di lapangan menunjukkan bahwa kemungkinan kreditur tidak hanya memiliki satu benda jaminan yang harus di cek maka pembayaran PNBP untuk pengecekan mengharuskan kreditur menyiapkan pengeluaran ekstra. Hal ini merupakan faktoryang menyebabkan kreditur enggan melakukan pengecekan.

Permasalahan hukum kedua bila jaminan itu tidak diroya lebih kepada teknis pendaftaran fidusia yang juga merupakan norma hukum. Pasal 17 Peraturan Pemerintah Nomor 21 Tahun 2015 menegaskan:

(1) Berdasarkan pemberitahuan penghapusan sebagaimana dimaksud dalam Pasal 16, Jaminan fidusia dihapus dari daftar jaminan fidusia dan diterbitkan keterangan penghapusan yang menyatakan sertifikat jaminan fidusia yang bersangkutan tidak berlaku lagi.

(2) Jika penerima fidusia, kuasa atau wakilnya tidak memberitahukan penghapusan jaminan fidusia sebagaimana dimaksud dalam Pasal 16 , jaminan fidusia yang bersangkutan tidak dapat didaftarkan kembali.

Pasal 17 telah menegaskan dengan jelas bahwa bila jaminan belum diroya maka tidak dapat daftarkan kembali. Keadaan ini akan sangat merugikan pemilik objek karena tidak dapat lagi menjadikan benda miliknya tersebut sebagai jaminan.

Kedua akibat hukum di atas, yakni adanya fidusia ulang dan objek jaminan tidak dapat didaftarkan kembali merupakan akibat hukum yang akan diterima oleh pemilik objek jaminan, sedangkan akibat hukum bagi kreditur tidak dinyatakan dan diatur secara tegas baik dalam UUJF, Peraturan Pemerintah Nomor 21 Tahun 2015 maupun Peraturan Menteri Keuangan Nomor 130/PMK.010/2012.

Gustav Radbruch seorang filsuf Jerman yang terkenal dengan teorinya mengenai tujuan hukum, menurutnya hukum memiliki tujuan, yakni keadilan, kepastian dan kemanfaatan. Dengan demikian, pengaturan roya sesungguhnya belum mencerminkan keadilan yang seharusnya merupakan tujuan dari pembentukan undang-undang.

\section{Hambatan Dalam Pelaksanaan Roya Fidusia di Kota Pekanbaru}

Hasil analisis dari wawancara yang dilakukan penulis maka dapat diketahui dalam pelaksanaan roya fidusia di Kota Pekanbaru masih terdapat banyak hambatan. Hambatan

${ }^{21}$ Ketut Marita Widyasari Puspita dkk, Pelaksanaan Pengikatan Jaminan Fidusia Perbankan, Jurnal Kertha Semaya, Volume 2, Nomor 1, Februari 2014, hlm. 4. 
ini menyebabkan tidak efektifnya pengaturan roya di Indonesia khususnya di Pekanbaru.

Teori efektifitas hukum dikemukakan oleh Bronislaw Malinowski dan Soerjono Soekanto. Bronislaw Malinowski (1884-1942) menyajikan teori efektifitas pengendalian sosial atau hukum. Bronislaw Malinowski menyajikan teori efektifitas hukum dengan menganalisis tiga masalah yang meliputi: ${ }^{22}$

1. Dalam masyarakat modern, tata tertib kemasyarakatan dijaga oleh suatu sistem pengendalian sosial yang bersifat memaksa, yaitu hukum untuk melaksanakannya hukum didukung oleh suatu sistem alat-alat kekuasaan (kepolisian, pengadilan dan sebagainya) yang diorganisasi oleh suatu negara.

2. Dalam masyarakat primitif alat-alat kekuasaan serupa itu kadang-kadang tidak ada.

3. Dengan demikian apakah dalam masyarakat primitif tidak ada hukum.

Menurut Soerjono Soekanto dalam teori efektifitas hukum bahwa efektif atau tidaknya suatu hukum ditentukan oleh 5 (lima) faktor, yaitu ${ }^{23}$

1. Faktor hukumnya sendiri (undangundang).

2. Faktor penegak hukum, yakni pihakpihak yang membentuk maupun menerapkan hukum.

3. Faktor sarana atau fasilitas yang mendukung penegakan hukum.
4. Faktor masyarakat, yakni lingkungan hukum tersebut berlaku atau diterapkan.

5. Faktor kebudayaan, yakni sebagai hasil karya, cipta dan rasa yang didasarkan pada karsa manusia di dalam pergaulan hidup.

Dari hasil penelitian penulis terhadap seluruh responden, tampak faktor-faktor dari teori efektifitas Soerjono Soekanto relevan dengan hambatan pada tiap-tiap faktor tersebut sebagaimana dapat dijelaskan sebagai berikut.

1. Faktor hukumnya sendiri (undang-undang) Adanya perintah roya tanpa adanya sanksi yang tegas dalam UUJF, Peraturan Pemerintah Nomor 21 Tahun 2015 maupun Peraturan Menteri Keuangan Nomor 130/ PMK.010/2012 menyebabkan aturan yang bersangkutan hanya bersifat regulatif. Pasal roya hanya bersifat regulative (mengatur) bukan imperative (memaksa) tidak satupun aturan roya yang mengatur maupun penjelasannya adanya sanksi. Namun, sesungguhnya sebagaimana pendapat Jimly Asshiddiqie dan Muchamad Ali Aafa'at, suatu norma valid merupakan suatu pernyataan yang bisa mengasumsikan eksistensi norma tersebut dan mengasumsikan bahwa norma itu memiliki kekuatan mengikat (binding force) terhadap orang yang perilakunya diatur. Aturan adalah hukum, dan hukum yang valid adalah norma. Jadi hukum adalah norma yang memberikan sanksi. ${ }^{24}$

${ }^{22}$ Koentjaraningrat dalam H. Salim HS, Erlies Septiana Nurbani, Penerapan Teori Hukum pada Penelitian Tesis dan Disertasi, (Jakarta: Raja Grafindo Persada, 2014), hlm. 305.

${ }^{23}$ Soerjono Soekanto, Faktor-faktor ....Op.Cit, hIm. 8.

${ }^{24}$ Jimly Asshiddiqie dan Muchamad Ali Aafa'at, Teori Hans Kelsen Tentang Hukum, (Jakarta: Konstitusi Press, 2012), hlm. 33. 
Jhon Austin yang merupakan tokoh mahzab Analytical Jurisprudence mengatakan bahwa untuk dapat disebut hukum menurut Austin diperlukan adanya unsur-unsur, yakni (1) Adanya seorang penguasa (souvereighnity), (2) Perintah (command), (3) Kewajiban menaatinya (duty), (4) Sanksi bagi mereka yang tidak taat (sanction).

Budiono Kusumohamidjojo mengatakan bahwa sebagai kaedah yang memaksa, hukum sesungguhnya tidak mempersoalkan apakah yang berurusan dengannya itu setuju ataupun tidak setuju dengan akibat hukum yang ditimbulkannya. Paksaan merupakan tindakan yang dilakukan terhadap seseorang, sehingga orang tersebut melakukan ataupun tidak melakukan suatu tindakan yang bertentangan dengan kehendaknya sendiri. ${ }^{25}$ Dengan demikian, keberadaan suatu sanksi dalam suatu norma dapat memberikan kepatuhan terhadap norma tersebut.

2. Faktor penegak hukum, yakni pihak pihak yang membentuk dan menegakkan hukum Dari wawancara yang dilakukan diperoleh informasi bahwa selama ini belum ada pengawasan dari Otoritas Jasa Keuangan (OJK). Responden belum pernah didatangi oleh petugas OJK. Namun, responden memperkirakan OJK baru mengawasi dalam tingkat pusat saja, meskipun pelaksanaan fidusia ini sesungguhnya dilaksanakan pada tingkat cabang dan unit. Dengan demikian, faktor penegakan hukum yang tidak maksimal menjadi salah satu faktor pula yang membuat tidak efektifnya aturan roya dilaksanakan. Dari wawancara yang dilakukan oleh peneliti, didapatkan informasi bahwa OJK tidak mendatangi penerima fidusia selama ini. Artinya, pelaksanaan pengawasan itu belum dilaksanakan sebagaimana seharusnya.

3. Faktor sarana atau fasilitas yang mendukung penegakan hukum

Meskipun Pasal 17 Pemerintah Nomor 21 Tahun 2015 telah menegaskan dengan jelas bahwa bila jaminan belum di roya maka tidak dapat daftarkan kembali. Namun, fidusia online sebagai sarana dan fasilitas pendaftaran tidak dapat melakukan penolakan terhadap pendaftaran atas objek yang sedang dalam penjaminan. Dengan demikian, masih terbuka lebar kemungkinan terjadinya fidusia ulang.

4. Faktor masyarakat, yakni lingkungan hukum tersebut berlaku atau diterapkan

Kurangnya sosialisasi kepada masyarakat mengenai fidusia khususnya roya fidusia mengakibatkan masyarakat tidak terlalu peduli terhadap regulasi yang ada. Keengganan membayar PNBP karena merasa berat menjadi faktor tidak dijalankannya pemeriksaan terlebih dahulu objek yang akan dijaminkan.

5. Faktor kebudayaan, yakni sebagai hasil karya, cipta dan rasa yang didasarkan pada karsa manusia di dalam pergaulan hidup Kesadaran akan pentingnya roya belum tampak dalam kehidupan masyarakat khususnya di Kota Pekanbaru. Berbeda dengan jaminan hak tanggungan yang sangat jelas status tanah sedang dalam penjaminan pada buku tanah, pada Bukti Kepemilikan Kendaraan Bermotor atau bukti kepemilikan benda bergerak lainnya tidak pernah tertulis status objek sedang

${ }^{25}$ Budiono kusumohamidjojo, Filasafat Hukum, Proplematiktertiban yang Adil, (Jakarta: Mandar Maju, 2011), hlm. 221. 
dalam penjaminan. Oleh karenanya, masyarakat tidak terlalu memperdulikan penghapusan karena tidak akan berpengaruh pada peralihan hak milik atas benda bergerak tersebut nantinya. Sehingga, kesadaran akan pentingnya roya tidak tumbuh dalam masyarakat.

\section{Upaya Mengatasi Hambatan Pelaksanaan Roya Fidusia di Kota Pekanbaru}

Hambatan pelaksanaan roya ini, khususnya di Kota Pekanbaru dapat diatasi dengan melakukan perubahan pada kelima faktor dalam teori efektifitas di atas.

1. Faktor hukumnya sendiri (undang-undang) Dari faktor undang undang ada upaya yang dapat dilakukan agar aturan roya dapat dilaksanakan dengan baik, yakni

a. Dengan memberikan aturan yang memiliki sanksi sehingga aturan roya tidak lagi bersifat regulative (mengatur) semata. Namun, bersifat imperative (memaksa) diharapkan dapat memberikan efek patuh pada kreditur sebagai pihak yang dibebani kewajiban untuk melakukan roya.

b. Menempatkan asas accessoir sebagaimana semestinya sehingga dalam penjaminan fidusia dapat dibuatkan sistem penghapusan otomatis bagi jaminan fidusia yang hapus karena pelunasan. Untuk itu, harus ada perubahan Undang-Undang Jaminan Fidusia
2. Faktor penegak hukum, yakni pihak-pihak yang membentuk dan menegakkan hukum. Pengawasan terhadap lembaga pembiayaan sangatlah diperlukan. Di Indonesia pengawasan ini dilakukan oleh Otoritas Jasa Keuangan (OJK). Keberadaan OJK merupakan amanat Pasal 34 Undang-Undang Nomor 3 Tahun 2004 tentang Perubahan Atas Undang-Undang Nomor 23 Tahun 1999 tentang Bank Indonesia. Lembaga ini bertugas untuk mengawasi industri perbankan, asuransi, dana pensiun, pasar modal, modal ventura, dan perusahaan pembiayaan, serta badanbadan lain yang menyelenggarakan pengelolaan dana masyarakat. ${ }^{26}$ Optimalisasi pengawasan OJK terhadap lembaga pembiayaan akan dapat memaksa lembaga pembiayaan untuk patuh akan aturan yang berlaku.

3. Faktor sarana atau fasilitas yang mendukung penegakan hukum.

Sarana fidusia online yang diselenggarakan oleh pemerintah mencoba mendukung penegakan hukum. Dibukanya akses kepada korporasi dan retail bertujuan untuk memudahkan masyarakat untuk mengetahui informasi dan melakukan pendaftaran ataupun penghapusan. Pembukaan akses ini telah dilakukan oleh Kemenkumham semenjak bulan Maret 2016. Saat ini, korporasi dan retail juga diberikan hak akses, seperti gambar di bawah ini:

\footnotetext{
${ }^{26}$ Adrian Sutedi, Aspek Hukum Otoritas Jasa Keuangan, (Jakarta:Raih Asa Sukses, 2004), hlm.38.
} 


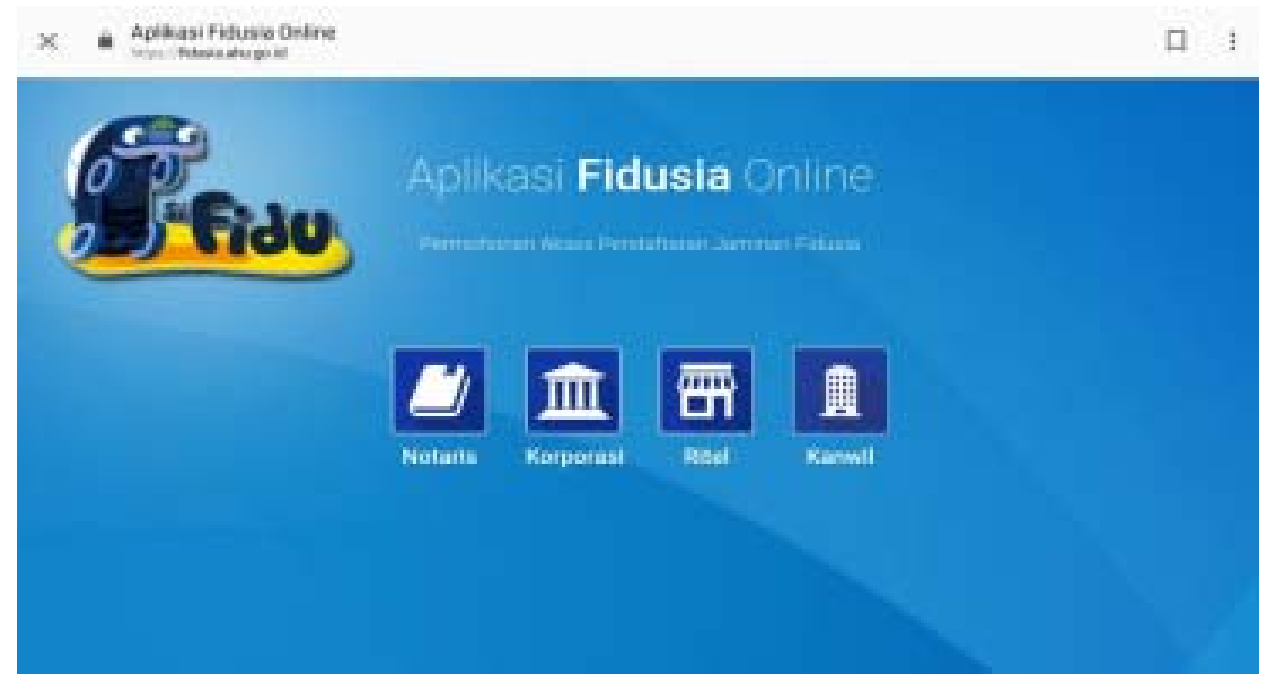

Gambar 3. Akses bagi Retail dan Korporasi pada Fidusia Online ${ }^{27}$

Pembukaan akses bagi korporasi dan retail akan dapat memudahkan retail dalam hal ini orang dan badan usaha atau korporasi yang terdiri dari lembaga keuangan bank dan non bank untuk melakukan roya fidusia. Selain itu, Kemenkumham juga harus melakukan penyempurnaan sistem yang dapat menolak pendaftaran fidusia terhadap objek jaminan yang sudah terdaftar namun belum dilakukan roya. Melalui prasarana ini, akan memberikan kepatuhan kepada masyarakat khususnya kepada penerima fidusia dan pemilik objek jaminan.

4. Faktor masyarakat, yakni lingkungan hukum tersebut berlaku atau diterapkan.

Melakukan sosialisasi tentang fidusia kepada masyarakat luas tidak terbatas hanya pada notaris dan perusahaan pembiayaan. Memanfaatkan media dalam sosialisasi akan efektif untuk memperkenalkan aturan dan sistem fidusia terutama roya fidusia.

5. Faktor kebudayaan, yakni sebagai hasil karya, cipta dan rasa yang didasarkan pada karsa manusia di dalam pergaulan hidup.
Bangsa Indonesia yang beraneka ragam dengan kultur budaya dan tingkat pengetahuan yang berbeda. Oleh karennya, sangat dimungkinkan perbedaan pemahaman tentang aturan roya jaminan fidusia. Dengan demikian, perlu adanya sosialisasi yang lebih intensif kepada masyarakat.

Bilamana kelima faktor ini dapat diupayakan pembenahannya maka efektifias aturan roya ini akan dapat terlaksana sebagaimana tujuan hukum, yakni memberikan kepastian hukum.

\section{Kesimpulan}

Pelaksanaan roya fidusia merupakan kewajiban hukum. Meskipun pendaftaran maupun penghapusan saat ini dapat dilakukan oleh korporasi, retail dan Kanwil Kemenkumham langsung selain oleh notaris, namun kenyataannya di wilayah Pekanbaru belum dapat meningkatkan kepatuhan terhadap pelaksanaan roya sebagaimana semestinya.

Pelaksanaan roya fidusia di Kota Pekanbaru masih terdapat banyak hambatan.

\footnotetext{
${ }^{27}$ Lihat https://fidusia.ahu.go.id/home.html.
} 
Hambatan ini menyebabkan tidak efektifnya pengaturan roya di Indonesia khususnya di Pekanbaru. Hambatan tersebut dapat dianalisis dengan menggunakan teori efektifitas. Adapun faktor-faktor penghambat efektifitas aturan roya di Pekanbaru, yaitu Pertama, faktor hukumnya sendiri (undang-undang) yang tidak memberikan aturan bersifat imperatif (memaksa), namun hanya bersifat regulative (mengatur). Kedua, faktor penegak hukum, yakni pihak yang membentuk dan menegakkan hukum. OJK sebagai pengawas lembaga keuangan belum melakukan pengawasan secara maksimal. Ketiga,faktor sarana atau fasilitas yang mendukung penegakan hukum. Fidusia online masih memiliki kekurangan. Salah satu kekurangan sistem fidusia online tidak mampunyai sistem untuk menolak pendaftaran objek jaminan yang sama didaftarkan kembali, namun belum dilakukan roya maka kemungkinan fidusia ulang terbuka. Oleh karenanya, perlu adanya penyempurnaan sistem. Keempat, faktor masyarakat, yakni lingkungan hukum tersebut berlaku atau diterapkan. Faktor masyarakat yang belum mengerti sistem fidusia online karena kurangnya sosialisasi. Perlu sosialisasi yang lebih luas cakupannya tidak hanya terbatas pada lembaga keuangan dan notaris saja, tetapi kepada masyarakat umum. Kelima, faktor kebudayaan, yakni sebagai hasil karya, cipta dan rasa yang didasarkan pada karsa manusia di dalam pergaulan hidup.Bangsa Indonesia yang beraneka ragam dengan kultur budaya dan tingkat pengetahuan yang berbeda. Oleh karennya, sangat dimungkinkan perbedaan pemahaman tentang aturan roya jaminan fidusia. Dengan demikian, perlu adanya sosialisasi yang lebih intensif kepada masyarakat.

\section{Saran}

Kepada Pemerintah disarankan melakukan perubahan regulasi maupun sistempendaftaran agar terciptanya harmonisasi peraturan dengan pelaksanaannya. Kepada Otoritas Jasa Keuangan harus melaksanakan pengawasan dengan baik atas kewajiban lembaga pembiayaan dan dapat memberikan sanksi tegas.Kepada perusahaan pembiayaan disarankan meningkatkan pengetahuan tentang kewajiban penerima fidusia karena sebagian besar jaminan dilakukan oleh lembaga pembiayaan dan bank.

\section{Referensi}

Adrian Sutedi. 2004.Aspek Hukum Otoritas Jasa Keuangan. Jakarta: Raih Asa Sukses.

Budiono kusumohamidjojo. 2011. Filasafat Hukum, Proplematiktertiban yang Adil. Jakarta: Mandar Maju.

Frieda Husni Hasbullah. 2005. Hukum Kebendaan Perdata, Hak-Hak yang Memberi Kenikmatan Jilid I. Jakarta: IndHill-Co, 2005.

H. Salim HS, Erlies Septiana Nurbani. 2014. Penerapan Teori Hukum pada Penelitian Tesis dan Disertasi. Jakarta: Raja Grafindo Persada, 2014.

Jatmiko Winarno.Perlindungan Hukum Bagi Kreditur Pada Perjanjian Jaminan Fidusia, Jurnal Independent. Volume 1. Nomor 1. Maret 2013.

Jimly Asshiddiqie dan Muchamad Ali Aafa'at. 2012. Teori Hans Kelsen Tentang Hukum. Jakarta: Konstitusi Press.

Ketut Marita Widyasari Puspita dkk. Pelaksanaan Pengikatan Jaminan Fidusia Perbankan.Jurnal Kertha Semaya. Volume 2. Nomor 1. Februari 2014. 
M.Bahsan. 2008. Hukum Jaminan dan Jaminan Kredit Perbankan Indonesia, Jakarta: Raja Grafindo Persada.

Miranda Fitraya. Akibat Hukum Terhadap Jaminan Fidusia yang Didaftarkan saat Terjadinya Kemacetan Pembayaran. Jurnal Braja Niti. Volume 1. Nomor 9. Tahun 2012.

Mokhamad Khoirul Huda dan Ninis Nugraheni. Perjanjian Jaminan Sebagai Accessoir Perjanjian Kredit. Jurnal Dialogia Iuridica. Volume 6. Nomor 2. Tahun 2015.
Opia Rendra. Tinjauan Yuridis Terhadap Fidusia Ulang Objek Tanpa Roya Fidusia Berdasarkan Undang-Undang Nomor 42 Tahun 1999.JOM Fakultas Hukum. Volume II. Nomor 2. Oktober 2015.

Soerjono Soekanto. 2008. Faktor-faktor yang Mempengaruhi Penegakan Hukum. Jakarta: PT Raja Grafindo Persada.

Tan Kamello. 2014. Hukum Jaminan Fidusia. Suatu Kebutuhan yang Didambakan. Bandung: Alumni. 